\title{
SOX2 wt Allele
}

National Cancer Institute

\section{Source}

National Cancer Institute. SOX2 wt Allele. NCI Thesaurus. Code C61137.

Human SOX2 wild-type allele is located within 3q26.3-q27 and is approximately $3 \mathrm{~kb}$ in length. This allele, which encodes transcription factor SOX-2 protein, is involved in the modulation of transcription by RNA polymerase II. 